\title{
Faktor-faktor yang Mempengaruhi Pendapatan Usahatani Jagung di Desa Bannae Kecamatan Insana Barat
}

\author{
Metriana Hoar Kehik ${ }^{\mathrm{a}}$ \\ ${ }^{a}$ Fakultas Pertanian, Universitas Timor, Kefamenanu, TTU - NTT, Indonesia.
}

\section{Article Info}

\section{Article history:}

Received 20 Maret 2018

Received in revised form 31 Mei 2018

Accepted 20 Juli 2018

\section{DOI:}

https://doi.org/10.32938/ag.v3i3.244

Keywords:

Faktor Produks

Jagung

Pendapatan

\section{Abstrak}

Penelitian ini bertujuan untuk mengetahui 1) gambaran usahatani jagung; 2) pendapatan yang diperoleh dari usahatani jagung; dan 3 ) faktor-faktor apa saja yang mempengaruhi pendapatan usahatani jagung di Desa Bannae Kecamatan Insana Barat. Penelitian dilaksanakan pada bulan Maret sampai bulan Agustus 2017. Teknik penentuan sampel dilakukan menggunakan teknik acak sederhana sehingga dari 415 yang berusahatani jagung diambil 80 responden. Metode analisis data dalam penelitian ini meliputi metode deskriptif kualitatif, analisis pendapatan dan analisis Cobb-Douglass. Hasil penelitian menunjukkan bahwa usahatani jagung di Desa Bannae Kecamatan Insana Barat Kabupaten TTU dilakukan melalui tahapan 1) persiapan lahan; 2) pemilihan benih jagung; 3) penanaman; 4 pemeliharaan; dan 5) panen dan pasca panen. Produksi jagung digunakan untuk konsumsi (19,69\%), sebagian dijual (40,08\%), bibit $(3,81 \%)$, lain-lain $(37,14 \%)$. Modal yang dikeluarkan untuk berusahatani jagung selama satu musim tanam sebesar Rp $15,200.000,00$ sedangkan total penerimaan yang diperoleh petani jagung sebesar Rp42.180.000,00 dari hasil penjualan jagung dengan rata-rata penerimaan sebesar Rp527.250,00 sehingga total pendapatan petani jagung sebesar Rp26.980.000,00 dengan rata-rata pendapatan sebesar Rp530.575,00. Secara simultan variabel modal, luas lahan, benih, tenaga kerja, pengalaman, pendidikan berpengaruh secara nyata terhadap pendapatan usahatani jagung pada $\alpha=5 \%$. Secara parsial variabel yang berpengaruh nyata yaitu luas lahan, pendidikan, tenaga kerja, jumlah penjualan sedangkan yang tidak berpengaruh nyata adalah benih, dan umur.

\section{Pendahuluan}

Pembangunan sektor pertanian merupakan bagian yang sangat penting bagi perekonomian Indonesia. Peranan sektor pertanian antara lain meningkatkan pendapatan dan taraf hidup petani dan nelayan, memperluas lapangan kerja dan kesempatan usaha. Salah satu sub sektor pertanian yang cukup strategis adalah sub sektor tanaman pangan. Sub sektor tanaman pangan semakin signifikan posisinya manakala dikaitkan dengan isu ketahanan pangan, baik pada skala rumah tangga maupun wilayah. Ketersediaan pangan yang cukup dan diserta kemudahan masyarakat untuk mendapatkannya akan menjamin terwujudnya upaya pencapaian dan peningkatan ketahanan pangan (Cahyadinata \& Sukiyono, 2008).

Jagung merupakan salah satu komoditi tanaman pangan yang potensial untuk dikembangkan karena sumber utama karbohidrat dan protein. Jagung menjadi salah satu komoditas pertanian yang sangat terkait dengan industri besar. Selain dikonsumsi sebagai sayuran, buah jagung juga dapat diolah menjadi aneka makanan. Selain itu pipilan keringnya dimanfaatkan untuk pakan ternak. Nilai kalori pada jagung mempunyai keunggulan bila dibandingkan dengan beras, karena jagung mengandung asam lemak esensial yang sangat bermanfaat bagi pencegahan penyakit pembuluh darah (Warisno, 2007)

Kabupaten Timor Tengah Utara (TTU) sebagai salah satu Kabupaten di Provinsi Nusa Tenggara Timur yang diprioritaskan untuk pengembangan tanaman jagung. Insana Barat merupakan salah satu kecamatan yang memberikan kontribusi terhadap produksi jagung di kabupaten TTU. Tahun 2013 kecamatan Insana Barat menghasilkan jagung 751 ton atau 1,2\% dari tota produksi jagung kabupaten TTU (63.677 ton) dengan luas panen 296 ha dan produktivitas 2,54 t/ha (BPS Kab. TTU, 2014). Tahun 2014 kecamatan Insana Barat menghasilkan jagung 1.039 ton atau $1,4 \%$ dari total produksi jagung kabupaten TTU (73.114 ton) dengan luas panen 380 ha dan produktivitas 2,73 t/ha (BPS Kab. TTU, 2015). Tahun 2015 kecamatan Insana Barat menghasilkan jagung 2.164 ton atau 3,8\% dari total produksi jagung kabupaten TTU (56.655 ton) dengan luas panen 1.035 ha dan produktivitas 2,09 t/ha (BPS Kab. TTU, 2017). Produktivitas jagung di kecamatan Insana Barat lebih tinggi dar beberapa hasil penelitian terdahulu di beberapa wilayah kabupaten TTU yakni 1 t/ha (Wonkay \& Taolin, 2016), dan 1,4 t/ha (Leki $d k k$., 2016) tetapi masih lebih rendah dari 3,54 t/ha yang dihasilkan dari penelitian Bhato, (2016). Selain sebagai bahan makanan pokok, jagung di kabupaten TTU juga telah dijadikan sebagai bahan baku industri kecil atau industri rumahan misalnya dimanfaatkan sebagai bahan baku agroindustri tortila atau kerupuk jagung (Falo \& Fallo, 2016) atau digunakan untuk membuat biskuit jagung (Kolo \& Hutapea, 2016).

Usahatani jagung di Desa Bannae Kecamatan Insana Barat bersifat sem komersial, sebagian produksi dikonsumsi dan sebagian besar dijual untuk menambah pendapatan petani dalam meningkatkan ekonomi keluarga. Produksi jagung di Desa Bannae Kecamatan Insana Barat mengalami fluktuasi dari tahun ke tahun karena pengaruh lingkungan dan penggunaan input. Penggunaan input produksi seperti benih, pupuk, pestisida dan luas lahan akan berpengaruh terhadap jumlah produksi yang dihasilkan. Perbedaan pengguna input akan mengakibatkan perbedaan hasil yang diperoleh. Selain itu penggunaan input yang tidak sesuai dengan standar yang dianjurkan juga dapat mempengaruhi hasil yang diperoleh. Produksi, faktor produksi (input dan biaya) mempengaruhi pendapatan usahatani jagung. Keterbatasan input dan biaya dapat mengurangi pendapatan petani dari usahatani jagung. Berdasarkan uraian tersebut maka perlu dilakukan penelitian dengan topik faktor-faktor yang mempengaruhi pendapatan usahatani jagung di Desa Bannae Kecamatan Insana Barat Kabupaten Timor Tengah Utara. Tujuan penelitian ini adalah untuk mengetahui 1) gambaran usahatani jagung; 2) pendapatan yang diperoleh dari usahatani jagung; dan 3) faktor-faktor apa saja yang mempengaruhi pendapatan usahatani jagung di Desa Bannae Kecamatan Insana Barat.

\section{Metode}

Penelitian dilaksanakan di Desa Bannae Kecamatan Insana Barat Kabupaten TTU pada bulan Maret sampai dengan bulan Agustus 2017 dengan mengambil data tahun 2016. Penelitian menggunakan metode survei. Data yang dikumpulkan berupa data primer dan sekunder. Data primer adalah datadata yang diperoleh melalui wawancara dengan responden dan observasi. Data sekunder merupakan data yang diperoleh dari instansi-instansi terkait Penentuan sampel dilakukan menggunakan teknik acak sederhana (simple random sampling) sehingga dari 415 yang berusahatani jagung diambil 80 responden untuk dijadikan sampel dalam penelitian ini.

Untuk mengetahui gambaran usahatani jagung digunakan analisis deskriptif kualitatif sesuai petunjuk Nasir, (2003). mengetahui pendapatan usahatani sawi maka dilakukan analisis pendapatan sesuai petunjuk Soekartawi, (1995), dengan formula $\mathrm{Pd}=\mathrm{TR}-\mathrm{TC}$ dimana:

$\mathrm{Pd}=$ Pendapatan Usahatani

$\mathrm{TR}=$ Total Penerimaan $/$ Total revenue

TC $=$ Total Biaya / total cost

Biaya produksi yang dikeluarkan oleh petani dihitung sesuai petunjuk Hadisapoetro, (1973). Untuk mengetahui faktor-faktor produksi yang mempengaruhi produksi usahatani jagung digunakan analisis regresi berganda dalam bentuk fungsi produksi Cobb-douglas sesuai petunjuk Soekartawi, (1990). Data primer yang diperoleh dari hasil wawancara dengan responden diolah dengan menggunakan bantuan software SPSS 16.0 yang dilakukan sesuai petunjuk Santoso, (2008)

\section{Hasil dan Pembahasan}

\subsection{Gambaran Usahatani Jagung}

Budidaya jagung yang dilakukan oleh petani Desa Bannae Kecamatan Insana Barat biasanya dilakukan pada awal musim hujan dan jenis jagung yang dibudidayakan adalah jenis jagung lokal putih. Pola tanam pada desa penelitian dengan menggunakan sistem tumpang sari dengan tanaman semusim lainnya seperti kacang tali, kacang hijau, kacang tanah, ubi kayu dan labu. Teknik budidaya jagung yang dilakukan oleh petani responden dimulai dari kegiatan persiapan lahan sampai pada panen dan pasca panen.

a. Persiapan Lahan

Persiapan lahan biasanya dilakukan pada musim kemarau yaitu pada bulan Agustus-Oktober. Persiapan lahan yang dilakukan di Desa Bannae yaitu dengan cara tebas bakar. Pengolahan lahan yang baru dengan menggunakan parang, sedangkan lahan yang lama diolah kembali dengan cara tanah dibalik menggunakan linggis atau pacul bertujuan untuk menggemburkan tanah sehingga tanaman jagung dapat tumbuh dengan baik dan juga memperbaiki pagar yang rusak. Waktu yang dibutuhkan untuk pengolahan lahan (1 minggu).

Setelah tanah diolah dilakukan pemupukan. Pupuk yang digunakan adalah pupuk urea dan TSP. Kedua pupuk dicampur dalam ember dan ditebarkan di atas tanah yang sudah dibalik dan dibiarkan untuk terkena sinar matahari. Ratarata pupuk urea yang digunakan sebanyak $5 \mathrm{~kg}$ sedangkan rata-rata pupuk TSP yang digunakan sebanyak $4 \mathrm{~kg}$. Jumlah petani yang memakai pupuk sebanyak 34 petani dan tidak memakai pupuk sebanyak 46 petani, total $35 \%$ dengan rerata $0,4375 \%$. Waktu pemupukan di lakukan pada pagi hari dan sore hari. Rata-rata curahan kerja yang digunakan untuk persiapan lahan sebanyak 29,35 HKO.

b. Pemilihan Benih

Benih yang digunakan yaitu jagung yang telah disimpan setelah panen tahun sebelumnya, pemilihan benih yang dilakukan oleh masyarakat Desa Bannae yaitu pertama jagung diluruh dan selanjutnya pisahkan biji jagung yang baik untuk ditanam. Ciri benih yang baik yang digunakan petani di lokasi penelitian yaitu memilih biji yang tidak fufuk atau tidak rusak. Waktu yang 
dibutuhkan untuk melakukan pemilihan benih 2-3 hari. Rata-rata curahan kerja yang digunakan untuk pemilihan benih sebesar 10,875 HKO.

c. Penanaman

Penanaman dilakukan pada awal saat musim turunnya hujan yaitu berkisar antara bulan November-Desember. Penanaman jagung di Desa Bannae secara tradisional yaitu setiap lubang diisi lebih dari 2 jenis tanaman sekalian seperti jagung, labu, kacang tali. Jagung ditanam dengan jarak 70 × $20 \mathrm{~cm}$, dengan menggunakan linggis. Setiap lubang diisi 3-4 biji jagung kemudian ditutup dengan tanah. Waktu yang dibutuhkan untuk penanaman jagung 3-4 hari. Ratarata curahan kerja yang digunakan untuk penanaman sebanyak 6,075 HKO.

d. Penyiangan

Penyiangan dilakukan dengan membersihkan gulma atau tanaman pengganggu yang tumbuh di sekitar tanaman jagung dengan tujuan untuk menyuburkan tanaman jagung. Penyiangan dilakukan pada saat tanaman jagung berumur 3-4 minggu, dengan menggunakan tajak atau linggis kecil. Penyiangan bertujuan untuk membersihkan gulma dan menggemburkan tanah sehingga tanaman jagung dapat tumbuh dengan baik. Waktu yang dibutuhkan untuk pembersihan gulma 5-6 hari. Rata-rata curahan kerja yang digunakan untuk penyiangan sebanyak 19,175 HKO.

\section{e. Panen}

Pemanenan dilakukan setelah tanaman jagung mencapai umur panen yaitu 3-4 bulan setelah tanam. Pemanenan dilakukan apabila jagung sudah tua dan kulit jagung sudah kuning dan mengering. Pemanenan jagung di Desa Bannae biasanya dilakukan dengan cara manual yaitu jagung dipatah lalu dikumpulkan dan disusun di dalam karung dan dibawa ke rumah. Waktu yang dibutuhkan untuk melakukan pemanenan sekitar 3-4 hari. Rata-rata curahan kerja yang digunakan untuk panen sebanyak $17,175 \mathrm{HKO}$.

\section{f. Pasca Panen}

Penanganan pasca panen biasanya dilakukan dengan cara mengeringkan, dan umumnya dengan menggunakan terpal atau tikar. Waktu yang dibutuhkan untuk penjemuran selama 5-6 hari bila matahari cerah. Rata-rata curahan kerja yang digunakan untuk pasca panen sebanyak 57,821 HKO.

\subsection{Pendapatan Usahatani Jagung}

a. Penerimaan

Penerimaan merupakan hasil perkalian antara produksi dengan harga jual jagung per $\mathrm{kg}$. Berdasarkan hasil analisis rata-rata produksi jagung yang diusahakan di Desa Bannae dalam satu kali musim tanam adalah $263 \mathrm{~kg}$ dan total produksi sebesar $21.046 \mathrm{~kg}$, dengan harga jual Rp5.000,00/kg di tingkat petani. Berdasarkan hasil penelitian total penerimaan usahatani jagung di Desa Bannae dalam satu kali musim tanam sebesar Rp42.180.000,00 dengan rata-rata penerimaan sebesar Rp527.250,00.

\section{b. Modal Usahatani}

Modal merupakan barang atau uang yang bersama-sama faktor produksi menghasilkan barang-barang baru dalam hal ini hasil petani. Berdasarkan hasil penelitian modal yang dikeluarkan untuk usahatani jagung di Desa Bannae sebesar Rp15.200.000,00. Total modal tersebut terdiri dari beberapa jenis yakni biaya pupuk sebesar Rp5.510.000,00 dengan rata-rata biaya sebesar Rp68.875,00, biaya konsumsi tenaga kerja sebesar Rp9.690.000,00 dengan rata-rata biaya sebesar Rp190.00,00.

c. Pendapatan

Pendapatan merupakan jumlah seluruh uang yang diterima oleh seseorang atau rumah tangga selama jangka waktu tertentu. Pendapatan usahatani jagung diperoleh dari selisih antara penerimaan jagung dengan total modal yang dikeluarkan. Berdasarkan hasil perhitungan diperoleh total penerimaan sebesar Rp42.180.000,00 dengan rata-rata penerimaan sebesar Rp527.250,00. Berdasarkan hasil perhitungan tersebut dapat diketahui total pendapatan petani jagung di Desa Bannae dengan menghitung selisih antara penerimaan dengan modal sehingga total pendapatan per tahun sebesar Rp26.980.000,00 dengan rata-rata pendapatan dari produksi sebesar Rp530.575,00. dan rata-rata pendapatan dari penjualan Rp337.250,00.

\subsection{Faktor-faktor yang Mempengaruhi Pendapatan}

Analisis yang digunakan pada penelitian ini adalah analisis regres berganda dalam bentuk logaritma dengan fungsi produksi Cobb-Douglas. Model matematis fungsi produk Cobb-Douglas dengan metode Ordinary Least Square (OLS). Fungsi Cobb-Douglas digunakan untuk menguji pengaruh antara variabel independen terhadap pendapatan jagung. Berdasarkan hasil analisis dapat diperolah hasil dari fungsi Cobb-Douglas yakni LnY $=\operatorname{Ln}-2,942+0,073 \operatorname{LnX}_{1}+0,185 \operatorname{LnX}_{2}+0,081 \operatorname{LnX}_{3}+0,049 \operatorname{LnX}_{4}+0,159 \mathrm{~L}$ $\mathrm{nX}_{5}+0,489 \operatorname{LnX}_{6}+0,295 \operatorname{LnX}_{7}$.

Uji kebaikan model menggunakan uji $\mathrm{F}$, uji t, dan koefisien determinasi. Uji $\mathrm{F}$ dilakukan untuk melihat bagaimana variabel independen (umur, pendidikan, luas lahan, benih, tenaga kerja, jumlah penjualan, dan dummy pupuk) secara bersama-sama atau simultan mempengaruhi variabel dependen (faktor pendapatan jagung) dengan membandingkan rata-rata kuadrat regresi dengan rata-rata kuadrat residu. $\mathrm{F}_{\text {hitung }}(62,613)>$ Ftabel $(1,664)$ dan nyata pada

taraf $1 \%$ dengan makna variabel bebas yang meliputi modal, luas lahan, benih, tenaga kerja, pengalaman usahatani, pendidikan petani secara bersamasama memiliki pengaruh nyata terhadap pendapatan jagung.

Uji t dilakukan untuk mengetahui pengaruh variabel bebas yang ditelit secara individual terhadap pendapatan jagung di Desa Bannae. a. $\operatorname{Umur}\left(\mathrm{X}_{1}\right)$

Hasil perhitungan menunjukkan bahwa $t_{\text {hitung }}(1,222)<t_{\text {tabel }}(1,664)$ maka faktor umur petani tidak berpengaruh terhadap pendapatan usahatani jagung. Hasil penelitian menunjukkan bahwa umur petani 51-60 masih produktif Disimpulkan bahwa umur semakin tua dan semakin mendekati usia tidak produktif maka tidak lagi berpengaruh terhadap pendapatan.

b. Pendidikan $\left(\mathrm{X}_{2}\right)$

Hasil perhitungan menunjukkan bahwa $t_{\text {hitung }}(2,621)>t_{\text {tabel }}(1,664)$ maka faktor pendidikan petani dikatakan memiliki pengaruh secara positif terhadap pendapatan usahatani jagung yang nyata. Pendidikan petani diukur berdasarkan jenjang pendidikan yang ditempuh oleh petani, pada daerah penelitian petani kebanyakan pendidikan responden yang diteliti pada tingkat SD. Dapat dijelaskan bahwa jika pendidikan petani bertambah $1 \%$ maka akan meningkatkan pendapatan sebesar $0,444 \%$ karena adopsi inovasi teknologi yang lebih baik.

c. Luas Lahan $\left(\mathrm{X}_{3}\right)$

Hasil perhitungan menunjukkan bahwa $t_{\text {hitung }}(1,484)<t_{\text {tabel }}(1,664)$ dengan demikian faktor luas lahan dikatakan tidak berpengaruh terhadap pendapatan usahatani jagung. Hal ini berarti semakin luas lahan yang digunakan untuk usahatani jagung maka semakin besar juga hasil yang didapatkan. Hal ini berbeda dengan yang dikemukakan oleh Kune $d k k$., (2016) dalam penelitiannya bahwa hubungan produksi menunjukkan luas lahan mempunyai koefisien yang positif sebesar 3,793.

d. Benih $\left(\mathrm{X}_{4}\right)$

Hasil perhitungan menunjukkan bahwa $t_{\text {hitung }}(0,849)<t_{\text {tabel }}(1,664)$ dengan demikian faktor benih dikatakan memiliki pengaruh yang tidak nyata terhadap pendapatan usahatani jagung. Dapat dijelaskan bahwa penggunaan benih di lokasi penelitian kurang berkualitas karena setiap tahun petani selalu menanam benih yang sama dari tahun ke tahun sehingga dapat mempengaruhi produksi dan pendapatan jagung.

e. Tenaga Kerja $\left(\mathrm{X}_{5}\right)$

Hasil perhitungan menunjukkan bahwa $t_{\text {hitung }}(2,789)>t_{\text {tabel }}(1,664)$ dengan demikian faktor tenaga kerja dikatakan berpengaruh terhadap pendapatan usahatani jagung. Hal ini berarti bertambahnya tenaga kerja dalam berusahatani jagung maka semakin besar pendapatan jagung. Artinya bahwa tenaga kerja petani diteliti secara optimal sehingga berpengaruh terhadap pendapatan jagung. Jika ada penambahan $1 \%$ tenaga kerja akan meningkatkan pendapatan sebesar $0,132 \%$

f. Jumlah Penjualan $\left(\mathrm{X}_{6}\right)$

Hasil perhitungan menunjukkan bahwa $t_{\text {hitung }}(6,594)>t_{\text {tabel }}(1,664)$. Dengan demikian faktor jumlah penjualan dikatakan memiliki pengaruh positif terhadap pendapatan usahatani jagung pada $\alpha=1 \%$. Artinya bahwa ketika jumlah penjualan ditambah $1 \%$ maka akan meningkatkan pendapatan sebesar $0,147 \%$.

g. $\quad$ Pupuk $\left(\mathrm{X}_{7}\right)$

Hasil perhitungan menunjukkan bahwa $t_{\text {hitung }}(4,400)>t_{\text {tabel }}(1,664)$ dengan demikian faktor penggunaan pupuk dikatakan berpengaruh terhadap pendapatan usahatani jagung pada $\alpha=1 \%$. Hal ini berarti semakin banyak penggunaan pupuk yang digunakan maka semakin besar juga hasil yang didapatkan, sehingga jika pupuk bertambah $1 \%$ akan meningkatkan pendapatan sebesar $0,318 \%$.

Koefisien determinasi $\left(\mathrm{R}^{2}\right)$ digunakan untuk melihat seberapa besar variabel independen berupa umur, pendidikan, luas lahan, benih, tenaga kerja, jumlah penjualan, dummy pupuk menjelaskan variabel dependen yakni pendapatan. Nilai $\mathrm{R}^{2}$ yang diperoleh sebesar 0,859 atau mencapai $85,9 \%$, angka tersebut menunjukkan bahwa kemampuan variabel bebas dalam memberikan informasi untuk menjelaskan keragaman variabel dependen pendapatan memiliki pengaruh sebesar $85,9 \%$. Sisanya $17,9 \%$ dipengaruhi oleh faktor lain yang tidak diteliti dalam penelitian ini.

\section{Simpulan}

Usahatani jagung di Desa Bannae Kecamatan Insana Barat Kabupaten TTU dilakukan melalui tahapan 1) persiapan lahan; 2) pemilihan benih jagung; 3) penanaman; 4) pemeliharaan; dan 5) panen dan pasca panen. Produksi jagung digunakan untuk konsumsi $(19,69 \%)$, sebagian dijual (40,08\%), bibit $(3,81 \%)$, lain-lain $(37,14 \%)$. Modal yang dikeluarkan untuk berusahatan jagung selama satu musim tanam sebesar Rp15.200.000,00 sedangkan total penerimaan yang diperoleh petani jagung sebesar Rp42.180.000,00 dari hasil penjualan jagung dengan rata-rata penerimaan sebesar Rp527.250,00 sehingga total pendapatan petani jagung sebesar Rp26.980.000,00 dengan rata-rata pendapatan sebesar Rp530.575,00. Secara simultan variabel modal, luas lahan, benih, tenaga kerja, pengalaman, pendidikan berpengaruh secara nyata terhadap pendapatan usahatani jagung pada $\alpha=5 \%$. Secara parsial variabel yang berpengaruh nyata yaitu luas lahan, pendidikan, tenaga kerja, jumlah penjualan sedangkan yang tidak berpengaruh nyata adalah benih, dan umur.

\section{Pustaka}

Bhato, M.A. 2016. Respon Pertumbuhan dan Hasil Jagung (Zea mays L.) Varietas Pioner terhadap Berbagai Takaran Pupuk Kandang Babi dan Jarak Tanam. Savana Cendana, 1(02): 85-89.

BPS Kab. TTU 2014. Timor Tengah Utara dalam Angka 2014. Kefamenanu: Badan Pusat Statistik Kabupaten TTU. 
BPS Kab. TTU 2015. Timor Tengah Utara dalam Angka 2015. Kefamenanu: Badan Pusat Statistik Kabupaten TTU.

BPS Kab. TTU 2017. Kabupaten Timor Tengah Utara dalam Angka 2017. Kefamenanu: Badan Pusat Statistik Kabupaten TTU.

Cahyadinata, I. \& Sukiyono, K. 2008. Partisipasi Pasar Petani Jagung dan Efeknya terhadap Marketed Surplus Jagung di Kabupaten Seluma Propinsi Bengkulu.

Falo, M. \& Fallo, Y.M. 2016. Kajian Pendapatan Agroindustri Tortila di Kecamatan Insana Barat Kabupaten Timor Tengah Utara. AGRIMOR, 1(02): 19-20.

Hadisapoetro, S. 1973. Pembangunan Pertanian. Yogyakarta: Departemen Ekonomi Pertanian Fakultas Pertanian, Universitas Gadjah Mada.

Kolo, D. \& Hutapea, A.N. 2016. Strategi Pengembangan Usaha Biskuit Jagung di Kelompok Wanita Tani Lestari Desa Subun Tua'lele, Kecamatan Insana Barat, Kabupaten Timor Tengah Utara. AGRIMOR, 1(03): 42-45.

Kune, S.J., Muhaimin, A.W. \& Setiawan, B. 2016. Analisis Efisiensi Teknis dan Alokatif Usahatani Jagung (Studi Kasus di Desa Bitefa Kecamatan Miomafo Timur Kabupaten Timor Tengah Utara). AGRIMOR, 1(01): 3-6.

Leki, W., Lelang, M.A. \& Taolin, R.I. 2016. Pengaruh Takaran Pupuk Kandang Sapi Terhadap Pertumbuhan dan Hasil Jagung (Zea mays, L.) yang Ditumpangsarikan dengan Kedelai (Glysine max,(L.) Merril). Savana Cendana, 1(01): 17-23.

Nasir, N. 2003. Metode Penelitian. Jakarta: Ghalia Indonesia.

Santoso, S. 2008. Panduan Lengkap Menguasai Spss 16. Jakarta: Elex Media Komputindo.

Soekartawi 1990. Teori Ekonomi Produksi dengan Pokok Bahasan Analisis Fungsi Cobb-Douglas. Depok: Rajawali Pers.

Soekartawi 1995. Analisis Usaha Tani. Jakarta: Universitas Indonesia Press.

Warisno 2007. Budi Daya Jagung Hibrida. Yogyakarta: Kanisius.

Wonkay, R.E. \& Taolin, R.I.C.O. 2016. Pengaruh Model Penyimpanan Benih dan Jenis Pupuk Kandang terhadap Pertumbuhan dan Hasil Jagung (Zea mays L.). Savana Cendana, 1(04): 128-132. 